\title{
117. Rotalidium, a New Genus of Foraminifera from the Pacific.
}

\author{
By Kiyosi Asano. \\ The Institute of Geology and Palaeontology, Tohoku Imperial \\ University, Sendai, Japan. \\ (Comm. by H. YABE, M.I.A., Dec. 12, 1936.)
}

While examining the foraminiferal fauna of the seas bordering Japan collected by the surveying ship Sôyô-maru of the Imperial Fisheries Experimental Station at Tôkyô, the following new form belonging to the Rotaliidae has been found; it is believed to represent a new genus.

Genus Rotalidium gen. nov.

Genotype:-Rotalidium pacificum Asano sp. nov.

Definition:-Test trochoid, all the whorls visible on the dorsal side, only the last whorl visible on the ventral side; chambers numerous, closely appressed, those of the last whorl superposed by supplementary chambers in a series on the ventral side of test; wall very finely perforate; surface smooth or ornamented with exogenous deposits; aperture a slit at the base of the last chamber. Recent, Japan.

This genus is interesting in its resemblance to certain genera of the Rotaliidae such as Eponidella ${ }^{1)}$ and Epistomaria. ${ }^{2)}$ Although these three genera are similar in having the supplementary chambers on the ventral side of test, the present form is easily distinguished from the others in different character of aperture and perforation of wall. Perhaps it is derived from a typical rotaloid form, probably Rotalia, ${ }^{3)}$ by the addition of supplementary chambers on the ventral side. Monotypic at present.

Rotalidium pacificum Asano sp. nov.

Figs. 1-3.

Test biconvex, rounded at periphery, ventral side more convex than the dorsal, usually 4 or 5 whorls, the last whorl composed of about 10 chambers; chambers all exposed on the dorsal side, rather uniform in shape, increasing very slightly in size as added, only those of the last whorl visible on the ventral side where a smaller supplementary chamber is added over the umbilical side of each chamber; sutures nearly straight on the dorsal side and somewhat depressed, channeled on ventral side; umbilical area covered by clear shell material with tubercles or bosses; wall smooth, polished on the dorsal side; aperture a narrow slit at the

1) J. A. Cushman \& H. D. Hedberg: A New Genus of Foraminifera from the Miocene of Venezuela, Contr. Cushman Lab. Foram. Res., vol. 11, pt. 1, 1935.

2) J. J. Galloway: A MANUAL OF FORAMINIFERA, 1933, p. 286.

3) J. J. Galloway: Ibid., p. 281.

J. A. Cushman: FORAMINIFERA THEIR CLASSIFICATION AND ECONOMIC USE, 2nd. Ed., 1933, p. 239. 
inner margin of the apertural face on the ventral side. Diameter up to $1 \mathrm{~mm}$. ; thickness about $0.6 \mathrm{~mm}$.

Holotype (Reg. No. 21395) and paratype (Reg. No. 21395), both from the Sôyô-maru station $329 ; 32^{\circ} 38^{\prime} 10^{\prime \prime} \mathrm{N}$. lat., $132^{\circ} 39^{\prime} 35^{\prime \prime} \mathrm{E}$. long., off Cape Asizuri, Sikoku, in 296 meters, sand and shells; bottom temperature $12.6 \mathrm{C}$.

The foraminifera fauna of this station is a very rich one; excluding the species described above, there are 67 species in 33 genera discriminated by the writer. A full account of these forms as well as the relation of the assemblage to those of the other stations will be given in a forthcoming paper on the recent foraminifera fauna of Japan.

Finally I wish to offer my warmest thanks to Dr. H. Marukawa of the Imperial Fisheries Experimental Station for kindly giving me permission to study the material, and to $\mathrm{Mr}$. H. Niino of the Imperial Fisheries Institute, both in Tôkyô, for his time taken in sorting out the material. Thanks are also due to Prof. H. Yabe of the Institute of Geology and Palaeontology, Tôhoku Imperial University, Sendai, for kindly submitting this short note for publication.

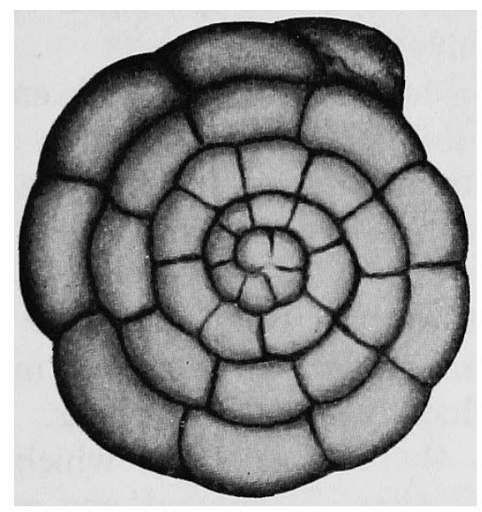

1.

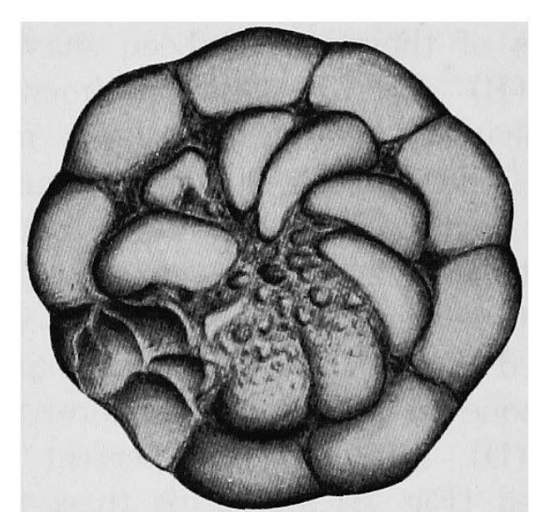

2.

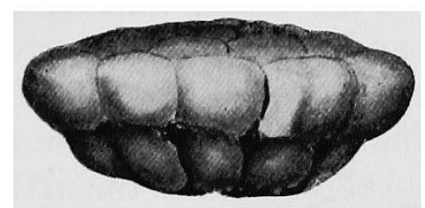

3.

Explanation of Figures. (K. Asano Del.)

Figs. 1-3. Rotalidium pacificum Asano sp. nov.

1. Dorsal side of holotype. $\times 50$

2. Ventral side of holotype. $\times 50$

3. Side view of paratype. $\times 50$ 